\title{
The Individual's Identity in the African Community
}

\author{
Gerishon Kuria Njuguna \\ Senior Lecturer \\ Egerton University \\ Faculty of Arts and Social Sciences \\ Department of Philosophy, History and Religious Studies \\ P. O. Box 536-20115, Egerton, Kenya
}

\begin{abstract}
The African person cannot be understood outside the context of the community.This study attempts to show that personhood exists even without the community thoughthe person may not achieve his full potential.The paper establishes that;every individual is born in and depends on the communityfor his identity and advancement;personhood is both inherent and conferred; an individual's behaviour is centred on the idea of vital energy; the individual is dynamic and personhood a process; rational reflection provides a basis for personhood; and that modernity has impacted on how a person identifies with the community. The study concludes that the community is important to the individual since through and in it he acquires his identity.Further, responding to contemporary situation of African values cannot be ignored. However, there is need to salvage some traditional African values in order torecover and promote the African identity.
\end{abstract}

Keywords: Individual, Community, Personhood

\subsection{Introduction}

The African person cannot be understood without making a special consideration to his relation with the community. The community presents the context in which the individual expresses him/herself as an independent and distinct being. This community is composed of individuals who are unique and unduplicatable and this uniqueness, identity and discreteness is expressed through many ways but in a clear way through names.

The important aspect of the person's identity is whether personhood is inherent or conferred. As an individual grows $\mathrm{s} / \mathrm{he}$ gains status and is given other positions in the community depending on his/her achievements. This study attempts to show that even though the community influences and shapes personhood, the person remains as such even without the community but may not grow to achieve the fullness of his potentialities. This means that the society does not in any way hinder one's personality, it harnesses and manifests it.

In African society, there is the reality of the vital force. The paper explains that all behaviour of an individual person is centred on the idea of vital energy. There is nothing that happens to an individual without a reason. For the Africans they sought to know why things happened the way they did. The reason behind what man couldn't

be explain made this person to behave well to maintain and enhance his vital energy. At the same time the individual does not exist as an isolated atom. The rites of passage give a clear guidance on how through them the person is identified. The study shows how the individual in his new status through the different rites is looked at by the community and the expectations of the community on him.

\subsection{Individual's Sociability}

The fundamentally relational character of the person and the interdependence of human individuals, arising out of their natural sociality is obvious. It is these necessary relationships that complete the being of the individual person who, without these relationships, would not be complete. Gyekye (2001) corroborates this point when he says that in the social context, in terms of functioning or flourishing in a human community, the individual person is not selfsufficient, his/her capacities, talents and dispositions are not adequate for the realization of his potential and basic needs..., what accrues from the person's natural sociality - and hence natural rationality - provides the buttress indispensable to the actualization of his/her possibilities. This means that an individual person is helpless economically, socially, religiously, and so forth without community. This is captured in Mbiti's (1990) famous assertion: "I am because we are, and since we are therefore I am." Nkemnkia (1999) observes that man is the most social being ever known on earth. This is because he is able to relate to others, with his own kind, with the surrounding world and with God, his creator. 
Man always has the other in mind; and every human act is directed towards the other. Everyone is aware of the other's value to which human acts are devoted. Thus all human acts are motivated by love and solidarity with the other. This love, Nkemkia (1999) asserts is the first characteristic of co-existence among human begins, without which there will be no points of contact, there is no community and it is not possible to discover the meaning of life.

Among the Bantu for example, Nkemnkia (1999) observes that, the expression "Muntu" finds its meaning in the idea and reality of the other. So, one can find the meaning of his own life only when he has found the meaning of the life of the other. To Bujo (2001) only common actions make the human person a human person and keeps him from becoming an unfettered ego. This is why any human being who behaves without consideration of interpersonal relationships and solidarity with the community is considered inhuman.

1.1.1 The Recognition of the Individual by the Community Every individual is born in a particular community and must participate in the life of the community. The community in turn recognizes the individual by giving him status and responsibilities. Mbiti (1990) observes that a person has to be born a member of a community and he cannot change tribal membership. Accordingly, the person cannot be converted from one tribe to another.

In some communities, when an individual undergoes initiation rites, s/he acquires personality and the community officially acknowledges him/her as its member. The individual knows s/he does not live of himself/herself but for the community and when the interests of the community are at stake, personal interests are of little importance, they must be sacrificed to community interest (Kanyike 2004). According to Bujo (1998) no one is allowed to keep this vitality for oneself; everyone has to share it with the other members of the family or clan. A person therefore does not feel threatened that others can harm him. He possesses self-assurance that comes from knowing that he belongs to a greater whole and is diminished when others are humiliated or diminished, when others are tortured or oppressed.

Unfortunately, more often than not, people think of themselves as mere individuals, separated from one another, whereas they are connected and what one does affects the whole world. The perturbing question from this exposition is whether the person is born a person or whether the personhood is conferred by the community and whether the influence of the community on the individual person in terms of giving the individual its (community's) customs, values, norms etc is the creation of the person.

\subsubsection{Personhood: Conferred or Inherent}

In recent years some philosophers, and especially the African philosophers, have been involved in serious debate about whether somebody becomes a person at birth, and so independent of the community or it is acquired, conferred or defined by the community. Menkiti (1984) observes that in Africa babies and minors are addressed with the pronoun 'it'. This according to him means that, children are not grown enough to acquire personhood, which we infer from this statement that personhood is acquired at a later stage in life. In support, Gyekye (2001) argues that there is relative absence of ritualized grief over the death of a child in African societies in contrast to the elaborate burial ceremony and ritualized grief in the event of the death of an older person. Further, Nyasani (1991) supports this view when he says, "my own individual life -

force is not mine by right or by nature. It is a gratuitous conferment from the ex post facto reality of those who already enjoyed it and jealously safeguard it for the purpose of continuity, social cohesion, social harmony, social and physical integrity and for realizing the teleological good of human (African) existence-the Mitsein in perpetual communion and perpetual vitality".

Here the author asserts the ontological primacy of the community. The reality of the communal world takes precedence over the reality of the individual life. To be person is realized through a community which is endowed with the capacity to satisfy it. This means that not all people acquire personhood, some fail to as Mbiti (1990) clearly points out that physical birth is not enough: the child must go through rites of incorporation so that it becomes fully integrated into the entire society. These rites continue throughout the physical life of the person, during which the individual passes from one stage of corporate existence to another.

The researcher contends that what is born of a woman cannot be anything short of a human being. The human person cannot be an "it", less person or no person. This kind of thinking can have severe implications morally in our society today, where abortion, research on stem cells etc can be admitted unchallenged.

\subsection{Dynamism of Person}

The community in African society took care of the individual in all dimensions and the individual contributed to the well-being of the community. The community moulded the individual person in all dimensions and the individual made reference to the community for guidance. Society shares its wisdom, both theoretical and practical, to the initiates during the rites of passage. 
That is, the individual who is part of the whole becomes the guardian of what the society holds. The initiate in this thinking discovers that s/he cannot be understood outside the community and his self-determination can only be understood in the context of the community. According to Beller (2001) the human being receives his subjectivity and identity through lineage, tradition and initiation. Therefore to be human is to know how to live accordingly within society. Society does not hinder one's personality, but it harnesses and manifests it. We can therefore conclude that it is only the person who is able to interact and participate in the life of the society, is able to discover him/herself as a muntu.

\subsubsection{Being and Vital Force}

The African recognizes that all beings are made of forces. Force is the nature of being, force is being, being is force (Tempels 1969).

Africans perceive the world of forces like a spider's web, in that no single thread may be caused to vibrate without shaking the whole network. All behaviour of an African is centred on the idea of vital energy. The origin, the subsistence, or annihilation of beings and forces is expressly and exclusively attributed to God. Doubtless that one force which is greater than another can paralyze it, diminish it, or even cause the operations of another to cease, but for all that, the force does not cease to exist.

The African concept of witchcraft, medicine, magic and sorcery is linked with the problem of being in Africa. At the same time the various ills, misfortunes, sickness, accidents, tragedies, sorrows, dangers etc which they experience is as a result of 'force'. The same powers can be employed for curative, protective, productive and preventive purpose. This is why Africans wear, carry or keep charms, amulets and a variety of other objects. These various aspects of African behaviour offer a holographic entry to African thought and the necessity of understanding of this vital force whose source is God. Vital force is the reality which is supreme in man. This understanding makes us to believe that the vital force is what the African person could not explain. When the cause was directly unidentifiable, the person termed the mystery a force. This is why the African believed that this force came from God who is Himself

a mystery. This made the African look at some stones, trees and other objects and termed them sacred. There was something peculiar about them, therefore the presence of force. This made the person develop some reverence and adoration of what he couldn't explain. The African individual therefore has to adjust accordingly through other activities and rites in the community to maintain the vital energy. According to the Africans the person undergoes some rites of passage that to the African eye increase the vital force. The person being dynamic undergoes through a process that gives him/her the understanding of his identity and eventually his/her personality.

\subsubsection{Person as a Process}

The human person as a process is understood from the rites of passage that cover the whole existential life of an individual African person from birth to death. The major stage in African life is the transition from child hood to adulthood, when they become fully institutionalized to the ethics of the group's culture.

The moments of naming, initiation, marriage and death, marks times of new beginning and transition from one life stage to another for the individual by dramatizing the transience of individual existence, while highlighting the social symbols that give the community its identity and integrate the person into a larger sphere of meaning.

Therefore a person is not only originated and sustained by processes but is in fact ongoing and inexorably characterized by them. This process is important in understanding the person for development and transformational process.

At the same time the rites of passage serve a double purpose, preserving the ongoing community as a symbol of collective immortality and permanence as well as providing a clear and guided means for transition from one life stage and sphere of responsibility to another. It is on this understanding, Kanyike (2004) opines that man is a being in transition: at no particular stage of his life can he rest. The child is on his way to adulthood, the adult is heading for old age, the old always grow older going steadily towards death and the dead to cross different stages leading to becoming ancestors.

It is from this understanding that nearly all African cultures believe that the infant has come from the spirit world with importance from that world and brings unique talents and gifts, indeed a unique purpose, mission, message or project to offer to the community and thus a reason for celebration. According to Mbiti (1990) nature brings the child into the world, but society creates the child into a social being, a corporate person. These rites of passage then bring about an ontological change, a deep transformation, a new way of

being which modifies and enables the person to live up to his/her new situation, i.e. to live like the ancestors and to prolong them worthily (Kanyike 2004). 


\subsection{Naming}

Naming is seen as an important part of the birth rite. It is believed that names have a spiritual vibration which affects the person as an infant, into adulthood and beyond. Tempels (1969) opines that the first criterion of defining an individual is through the name. The name expresses the individual character of the being. The name is not a simple external courtesy; it is the very reality of the individual. It is from this understanding that Tempels (1969) differentiates the African names and the European names. While the native name indicates the fact who the child is, the Christian name is something incidental, foreign and European.

Various communities in Africa name their children on varying days. However regardless of when the ceremony takes place, what is underscored is that existence is first and foremost a social experience, a corporate experience, not an individual one. The name given further assigns him or her a place in the family, the community and the universe. All members participate in the naming ceremony because the child belongs to the whole community and because all

have a stake in its proper insertion in the society. Mbiti (1990) observes that there is no stop to the giving of names in many African societies, so a person can acquire a sizeable collection of names by the time he becomes an old man and this makes the family names irrelevant in some communities because each individual has a particular name.

\subsubsection{The Name given at Birth}

According to Tempels (1969) this is the inner name, the life name, or the name of being. To Magesa (1998) it is also called the 'womb name,' 'name of the stomach,' 'the name of the umbilical cord,' 'the inner name,' or 'the spirit name. This name should be understood in the sense of real ontological dependence. This name is the living unchangeable name, the name establishing the individuality of the being. Nyamiti (1988) observes that to confer a name is therefore to confer personality, status, destiny, or express a wish or circumstances in which the bearer of the name was born. With this name, the child is finally taken possession of by the clan. An individual is defined by his name; he is his name. The inside name is the indicator of a person's individuality within his lineage. The name is sacred touching the very core of the person; it may not be bandied about, particularly in jest, as it belongs first of all to the ancestors and elders, who deserve respect. Perhaps that is why it is not frequently used except for serious occasions (Wagner 1972). Consequently, through the name the person is given identity and welcomed in to the society. In reference to the clan and how the individual is initiated in the community, Tempels (1969) observes that every newly born is therefore named with an interior name chosen from the names, that is to say from the individuals who constitute the clan. The Bantu will say to the newly delivered mother: 'You have born our grandfather, our aunt, our uncle etc.' The same ancestor can be reborn or can return in several living members of the same clan. Nyasani (2011) observes that, with reincarnation, the memory of the deceased venerable member of the society could not become obsolete at any one given stage of this corporate mystic existence.

The young child was encouraged to be like the ancestor he/she is named after and replicate all the things that made him/her famous and admirable. This constant and sustained encouragement sometimes succeeded according to Nyasani (2011) to produce a perfect replica or even a much more indomitable warrior who became the icon of the village and a living symbol of solidarity with the ancestral ascendancy and control over the community of the living members on earth. The impact of these incarnations cannot be underestimated because "a climate of social equilibrium and a modicum of social harmony was generated for so long as the villagers acknowledged and cherished the deeds of the deceased hero incarnate (Nyasani 2011).

In this connection, there were also names given after the relatives. The Agikuyu have a very precise and strict method of naming new born after their relatives. The method is so clear that one does not labour to know the name of the new child as long as he knows its gender. The first son is always named after the paternal grandfather while the first daughter takes the name of the paternal grandmother. The second son and daughter take the names of the maternal grandparents. The other grandchildren are alternatively named from each side always starting with the paternal side. They take the names of the sisters and brothers of their parents.

The researcher correctly infers from the preceding that reincarnation is real, but in the sense that the life force of the deceased comes to inhabit, protect and shape the character of the child.

\subsubsection{Names Chosen by the Individual}

These are names that are chosen by the individual or the individual assigns the name to himself. These names serve only to indicate the person, without having any profound relationship to the person or to his individuality. This is why Tempels (1969) says that these are names which are changed or abandoned at the will of him to whom it belongs. They often describe one's beauty or prowess or have no meaning at all having been chosen because of their sound or, in the case of boys, merely for their coarseness. They indicate the individual is in a new stage of life and enjoys a certain amount of independence that has to be reckoned with (Magesa 1998). 
These names have an empowering psychological effect on the individual, because they represent the identity or the personality the person would want the society to have regarding him. The person will therefore strive and make sure that he lives up to the name which he/she chose. The society on the other hand will expect to witness the character entailed in the name. It is established that a name has a very significant meaning to the person as it indicates the identity and personality of the individual. Today we observe that the European names given to Africans fall under this category but on the contrary some of these names do not have a specific meaning and may not add any psychological value to the person.

\subsection{Initiation: A Process of Rebirth}

After the child has been introduced to the corporate community, he must grow out of childhood into adulthood both physically, socially and religiously, a change from passive to active membership in the community. This according to Mbiti (1990) is one of the key moments in the rhythm of the individual life which is also the rhythm of the corporate group of which the individual is a part. To some people it is a sacred rite full of mystic significance, for others it is a civil rite, a jealous ethnical sign, for others it is just a sanitary operation surrounded with prejudices and beliefs altogether inconsistent with the operation itself. To the Agikuyu for example, circumcision was not a mere episode in their life, but a definite stage at which individuals who underwent the rite became men and women and were made adult members of the community, vested with social rights and obligations.

Mbiti (1990) affirms that the youths are ritually introduced to the art of communal living. This happens when they withdraw from other people to live alone in the forest or in specifically prepared huts away from the villages. They go through a period of withdrawal from society, absence from home, during which time they receive secret instruction before they allowed to re-join their relatives at home. This is a symbolic experience of the process of dying, living in the spirit world and being reborn. The rebirth, that is the act of re- joining their families, emphasizes and dramatizes that the young people are now new, they have new personalities, they have lost their childhood, and in some societies they even receive completely new names. An uncircumcised person was looked upon as a foreigner in the community, and such a man could not marry, on account of the deep rooted prejudice among the people, and the conviction that he could not have children. To be uncircumcised was to be the general laughing stock, a butt for derision and contempt; such a person had either to be a mere child and treated as such, or he was abnormal. An insult very much resented by Agikuyu was to be called Kahii, among the Kalenjin Ngetai both meaning uncircumcised boy.

Conclusively, it is realized that initiation rites were part of the traditional cycle of individual life. Initiation was not only a physical operation but mentally reinforced the person to act not as a child anymore but like a mature and respectable adult. This is why out of it, a young initiate must portray maturity, courage, responsibility and undertakes acts that are constant with his/her new status and expectations in the society. This in itself is a psychological enhancement to the personality of the individual.

\subsection{Marriage as a Rhythm of Life}

Marriage is the focus for existence. It is during marriage that the living, the departed and the unborn meet. Marriage is a duty, a requirement from the corporate society and a rhythm of life in which everyone must participate. If one does not take part in it, Mbiti (1990), it is a curse to the community, he is a rebel and a law breaker, he is not only abnormal but 'under human. It is important to note that marriage and procreation in African society form a unity which attempt to recapture the lost gift of immortality. Through reproduction, the chain of humanity is perpetuated. In many societies the marriage process is complete only when, according to Mbiti (1990), the first child is born or when all the marriage presents have been paid or even when one's first children are married.

\subsection{Responsibility and Free Will}

An important condition for one to achieve personhood is the ability to act on the basis of rational reflection. One is regarded as not being a person proper if his/her behaviour is unpredictable. An individual is responsible to the extent that his/her conduct can be modified through rational persuasion or moral correction. Where there is free will there is responsibility. According to Lee (2004), the normative idea of personhood depends on the metaphysical view that a person has volition, is autonomous, moral and capable of rational deliberation. The absence of metaphysical features of personhood such as voluntariness or freedom implies that one cannot rationally act to meet communal obligations. Recognition is a validation of one's ability to act voluntarily and freely to meet one's responsibilities based on reason.

The question here remains; what does the society do to those who are born incapacitated, in such a way they are not in a position to achieve personhood in ways that able bodied people can? How does one account for equality in unequal circumstances? 
The implication is that such people like idiots, senile, imbeciles, kleptomaniac, or neurosis agents, moral outlaws, social deviants, dumb and deaf, even children are left out on the basis that they cannot fully actualize the salient characteristic feature for being a person. In this judgment the community will be changing irresponsibility to nonresponsibility. It is against this background that we assert that free will and responsibility go together.

\subsection{Personhood and Social Status}

The researcher recognizes that there are standards for which individual persons aim that have an important role in how people think for themselves and their place in the society. But at the same time facts about a person's ambitions or goals do not add or subtract from that individual's status as a person. Wiredu (1996) asserts that the individual may fail in his strivings and, in the Akan Community, for example, may consequently be judged as a "useless person"

(onipa hun), an opprobrium term. But it must be noted that what the individual would be striving for in all these exertions is some social status not personhood. The striving is part of the individual's self- expression, an exercise of a capacity he has as a person. Even if at the end of the day he failed to attain the expected status, his personhood would not for that reason diminish, even though he may loose social respect in the eyes of the community. So that it is the social status not personhood at which individuals could fail (Wiredu 1996).

While persons may differ with respect to how they are treated in a community, the researcher holds that this difference is a matter of the social status accorded each, not facts about their status as persons. We point out that we are human beings before we are anything else. Human persons are as members of the 'kingdom of ends' (Kant's categorical imperative) equal independent of their empirical or accidental characteristics (be they social or genetic qualities). The researcher holds that it is our essentially human capacity for reason- not other fortuitous or accidental predicates, that serve as the basis of our worth. In this understanding, we point out that accidental characteristics as height, gender, age, marital status or social class are not the basis of personhood.

\subsection{The African Concept of the Human Person and the Wind of Change.}

Mbiti (1995) remarks that now a new and rapid rhythm is beating from the drums of science and technology, modern communication and mass media, schools and universities, cities and towns. The man of Africa must get up and dance on the arena of the world drama.

The image of the African person has changed because of this modernity. The African has changed his/her way of looking at him/herself and the universe. Such a change has impacted a great deal on personal attitudes and behaviour as well as interpersonal relationships. At the heart of life in the traditional African community was the integral formation of the persona responsible and fruitful experience of life. In contemporary society, some of the emerging issues are ignorance, erosion of the meaningfulness and evaluation of African values using Western criteria. This has led to the disintegration of the moral fabric of society, breakdown of the African family synergy, alienation of individuals and societies from their roots, giving rise to an individualistic society as opposed to communal life emphasized by the traditional African way of life.

\subsection{Conclusion}

This paper has expounded on the communal aspect of the human person. It has clearly shown the importance of community to the

individual and how the person acquires personhood and participates in the life of community. It is maintained that by the very fact that each individual is a person and expresses him/herself, s/he requires communication with the other in the order of knowledge and affection. Personality by its very essence requires dialogue in which individuals can properly communicate.

However, one cannot avoid responding to the contemporary situation of African values. The paper contends that there is need to salvage some traditional African values like family synergy which is the foundation for recovering and promoting the African identity. This can be done in an interactive way that supports integration and adoption of values from other cultures to enrich African value systems rather than destroying them.

The study also looked at the person as a process. People's names are given at different times. It is established that names have a spiritual vibration which affects the person as an infant, into adulthood and beyond. A name is given as reflection of the person's personality or life mission/purpose and serves as a powerful tool and reminder. After naming, we have looked at the initiation as process of rebirth, from childhood to adulthood and marriage with all its implications. 


\section{References}

Beller, R., (2001), Life and Community in Africa: A way towards Inculturation with Spirituality of Focolare. Nairobi: Pauline Publications Africa.

Bujo, B., (1998), The Ethical Dimensions of Community, Nairobi, Pauline Publication Africa.

Bujo, B., (2001) Foundation of an Africa Ethic: Beyond the Universal Claims of Western Morality, A Herder and Herder book, Crossroad pub.

Gykye, K., (2001), "Person and Community in Africa thought", in African Philosophy Reader, eds. P.H. Coetzee-A.P.J Roux, London: Routledge.

Kanyike E., (2004), The Principles of Participation in African Cosmology and Anthropology, Balaka, Montfort Media. Lee, B. M., (2004), African Philosophy: New and Traditional Perspectives, New York: Oxford University Press.

Magesa, L., (1998), African Religion, The Moral Traditions of Abundant Life, Nairobi: Kolbe Press.

Mbiti J., (1990), African Religions and Philosophy, 2nd ed., Oxford: Heinemann Educational Publishers.

Mbiti, J., (1995), Introduction to African Religion, 2nd ed., Nairobi: East African Educational Publishers.

Menkiti, A.I., (1984), Person and Community in African

Traditional Thought," in R.A. Wright (ed), African Philosophy: An Introduction, 3rd Edition Lan Ham: University Press of America.

Nkemnkia, M. N., (1999), Africa Vitology: A step forward in African Thinking, Nairobi: Pauline Publications Africa.

Nyamiti, C., (1988), The Naming Ceremony in the Trinity: An African Onomastic Approach to the Trinity," in CHIEA African Christian Studies, Vol. 4, No. 1

Nyasani, J., (1991), "The Ontological Significance of 'I' and 'We' in African Philosophy”, in C.H.I.E.A African Christian studies, Vol. 7, No. 1,

Nyasani, J. M., (2011) The Meaning and Implications of Life and Death in Africa: A Psycho-philosophical Reflection, Nairobi: Consolata Institute of Philosophy Press.

Temples, P., (1969), Bantu Philosophy, Paris: Presence Africane. Wagner, G., (1970) The Bantu of Western Kenya; with special reference to the Vugusu and Logoli, vol. 1, Newyork, Oxford University Press.

Wiredu, K., (1996), Cultural Universals and Particulars: an African Perspective, Indiana University Press. 